\section{Intermittent Light from a Rotating High-pressure Sodium Lamp Promotes Flowering of Long-day Plants}

\author{
Matthew G. Blanchard ${ }^{1}$ and Erik S. Runkle ${ }^{2,3}$ \\ Department of Horticulture, Michigan State University, A288 PSSB, East \\ Lansing, MI 48823
}

Additional index words. Campanula carpatica, Coreopsis grandiflora, night interruption, Petunia $\times$ hybrida, photoperiodic lighting, Rudbeckia hirta

\begin{abstract}
A technology for long-day (LD) lighting was evaluated for commercial production of ornamentals using a stationary high-pressure sodium (HPS) lamp with an oscillating aluminum parabolic reflector (rotating HPS lamp). We performed an experiment with four LD species (Campanula carpatica Jacq., Coreopsis grandiflora Hogg ex Sweet, Petunia $\times$ hybrida Vilm.-Andr., and Rudbeckia hirta L.) to compare the efficacy of a rotating HPS lamp in promoting flowering with night-interruption (NI) lighting using incandescent (INC) lamps. Seedlings were grown under natural short-day (SD) photoperiods (12 h or less) and NI treatments were delivered from a 600-W rotating HPS lamp mounted at one gable end of the greenhouse or from INC lamps that were illuminated continuously for $4 \mathrm{~h}$ or cyclically for $6 \mathrm{~min}$ every $30 \mathrm{~min}$ for $4 \mathrm{~h}$. Plants were grown at lateral distances of $1,4,7,10$, or $13 \mathrm{~m}$ from the rotating HPS lamp, which provided a maximum photosynthetic photon flux of $25.4 \mu \mathrm{mol} \cdot \mathrm{m}^{-2} \cdot \mathrm{s}^{-1}$ (at $1 \mathrm{~m}$ ) to 0.3 $\mu \mathrm{mol} \cdot \mathrm{m}^{-2} \cdot \mathrm{s}^{-1}$ (at $13 \mathrm{~m}$ ). Control plants were grown under an uninterrupted $15-\mathrm{h}$ skotoperiod. Within 16 weeks, $80 \%$ or greater of the plants within each species that received NI lighting had a macroscopic visible flower bud or inflorescence, whereas all species but Petunia $\times$ hybrida remained vegetative under the SD. Flowering of all species grown at $13 \mathrm{~m}$ from the rotating HPS lamp was delayed by 14 to $31 \mathrm{~d}$ compared with those under continuous INC. The weekly operational costs to provide NI lighting to a 139- $\mathrm{m}^{2}$ greenhouse with one $600-\mathrm{W}$ rotating HPS lamp or a standard cyclic INC lamp installation was estimated to be $80 \%$ to $83 \%$ lower compared with INC lighting for the entire 4-h NI. These results indicate that a rotating HPS lamp can be used to efficiently deliver LD lighting, but flowering time was delayed and flower number reduced in some species when the maximum NI light intensity was less than $2.4 \mu \mathrm{mol} \cdot \mathrm{m}^{-2} \cdot \mathrm{s}^{-1}$.
\end{abstract}

During commercial production of floriculture crops, photoperiod is often manipulated to induce or prevent flowering in species that are photoperiodic. Species have been classified into photoperiodic response categories according to how the length of the skotoperiod controls flowering and development (Vince-Prue, 1975). Long-day (LD) plants are those in which flowering is promoted under periods of darkness for less than a species-specific critical duration, whereas short-day (SD) plants flower only, or flower most rapidly, when the dark period exceeds a critical duration. LD and SD plants can be classified according to whether the photope-

\footnotetext{
Received for publication 21 July 2009. Accepted for publication 2 Dec. 2009

We gratefully acknowledge funding by Michigan's plant agriculture initiative at Michigan State University (Project GREEEN), the Michigan Agricultural Experiment Station, and greenhouse growers providing support for Michigan State University floriculture research. We also thank Raker's Acres for their contributions to this project and Mike Olrich for his greenhouse assistance.

${ }^{1}$ Postdoctoral Research Associate.

${ }^{2}$ Associate Professor and Extension Specialist.

${ }^{3}$ To whom reprint requests should be addressed; e-mail runkleer@msu.edu.
}

from cool-white fluorescent, high-pressure sodium (HPS), incandescent (INC), or metal halide lamps (Whitman et al., 1998). An alternative method to deliver photoperiodic lighting is to truncate the period of darkness by providing night-interruption (NI) lighting (Vince-Prue, 1975). During a 24-h cycle, complete, rapid, and uniform flowering of most LD species occurs when plants are illuminated with low-intensity lighting ( $2 \mu \mathrm{mol} \cdot \mathrm{m}^{-2} \cdot \mathrm{s}^{-1}$ or greater) for $4 \mathrm{~h}$ continuously during the middle of the dark period (e.g., 2200 to $0200 \mathrm{HR}$ ) (Mattson and Erwin, 2005; Runkle et al., 1998; Vince-Prue, 1975). In some LD species, less than $4 \mathrm{~h}$ of continual NI can delay flowering. For example, in the obligate LD plant Rudbeckia fulgida Ait. 'Goldsturm', a 1- or 2-h NI delayed flowering by $22 \mathrm{~d}$ compared with a 4-h NI (Runkle et al., 1998). Similarly, time to visible flower bud in the quantitative LD plant Petunia $\times$ hybrida 'Red Cascade' increased from 21 to $50 \mathrm{~d}$ as the duration of NI lighting decreased from 4 to $0.5 \mathrm{~h}$ (Vince-Prue, 1975).

Another NI lighting strategy is to provide cyclic or intermittent lighting. During cyclic lighting, INC lamps are turned on and off at specific intervals for a certain duration. Runkle et al. (1998) reported that LD herbaceous perennials Campanula carpatica 'Blue Clips', Coreopsis verticillata 'Moonbeam', Echinacea purpurea Moench 'Bravado', and Hibiscus moscheutos L. 'Disco Belle Mixed' grown under $4 \mathrm{~h}$ of cyclic NI lighting (6 min every $30 \mathrm{~min}$ ) from INC lamps flowered comparably with those grown under a continuous 4-h NI. In the quantitative LD plant Antirrhinum majus L. 'Jackpot', a 4-h NI with INC lamps operating for 10,15 , or $30 \mathrm{~s} \cdot \mathrm{min}^{-1}$ elicited the same flowering response as that of plants grown under continual NI (Maginnes and Langhans, 1967). Johansson (1976) reported that the quantitative LD plant Calceolaria $\times$ herbeohybrida Voss. flowered similarly under day-extension lighting delivered from either continuous INC or cyclic INC that operated $4 \mathrm{~min}$ every $10 \mathrm{~min}$.

An alternative system for LD lighting was developed and patented by the U.S. Department of Agriculture Forest Service and then commercially licensed in 2001 to Hydrofarm, Inc., Petaluma, CA (Tinus, 1995; U.S. Dept. of Agriculture Forest Service, 2001; U.S. Patent Office, 1992). This lighting system consists of a stationary HPS lamp with an oscillating aluminum parabolic reflector (rotating HPS lamp) that rotates $180^{\circ}$. The rotating HPS lamp can be mounted above a crop to provide an intermittent beam of light over the growing area. A rotating HPS lamp has been effective at preventing seedling dormancy in several coniferous species when used during the night (Omi and Eggleston, 1993; Tinus, 1995). For example, a 400-W rotating HPS lamp operated continuously throughout the night prevented apical bud development in Picea pungens Engelm. during natural short photoperiods at distances $13 \mathrm{~m}$ or less and under an irradiance as low as $0.5 \mu \mathrm{mol} \cdot \mathrm{m}^{-2} \cdot \mathrm{s}^{-1}$ (Tinus, 1995). Blanchard and Runkle (2009) compared the 
efficacy of a $600-\mathrm{W}$ rotating HPS lamp with INC lamps, but the reflector on the rotating HPS lamp stopped oscillating after $35 \mathrm{~d}$, and thus the results were considered preliminary. Here, we report results of a similar study in which our objectives were 1) to compare the efficacy of a rotating HPS lamp on flower induction in LD floriculture crops with traditional INC NI lighting methods; and 2) to compare the operational costs to deliver NI with different lighting systems.

\section{Materials and Methods}

Plant material and culture. On 17 Sept. 2007, seedlings of Petunia $\times$ hybrida 'Easy Wave Coral Reef' and Rudbeckia hirta 'Becky Cinnamon Bicolor' grown in 288cell plug trays $(6 \mathrm{~mL})$ were received from a commercial greenhouse (Raker's Acres, Inc., Litchfield, MI). Seedlings were subsequently grown in an environmental growth chamber at a constant temperature set point of $20{ }^{\circ} \mathrm{C}$ and under a mean photosynthetic photon flux $(P P F)$ of $160 \mu \mathrm{mol} \cdot \mathrm{m}^{-2} \cdot \mathrm{s}^{-1}$ [as measured with a line quantum sensor (Apogee Instruments, Inc., Logan, UT)] provided by cool-white fluorescent (F96T12CWVHO; Philips, Somerset, NJ) and INC lamps with a 9-h photoperiod. The calculated mean daily air temperature (MDT) inside the chamber was $19.4{ }^{\circ} \mathrm{C}$. On 14 Nov. 2007, seedlings of Campanula carpatica 'Pearl Deep Blue' and Coreopsis grandiflora 'Early Sunrise' grown in 128-cell (12-mL) plug trays were received from the same commercial greenhouse and were grown until transplant in an environmental growth chamber as described previously but at an MDT of $21.0{ }^{\circ} \mathrm{C}$. Plants were irrigated as necessary with acidified well water (containing 95, 34, and $29 \mathrm{mg} \cdot \mathrm{L}^{-1}$ calcium, magnesium, and sulfur, respectively) supplemented with a water-soluble fertilizer providing $\left(\mathrm{mg} \cdot \mathrm{L}^{-1}\right) 62$ nitrogen, 6 phosphorus, 62 potassium, 7 calcium, 0.5 iron, 0.3 copper, manganese, and zinc and 0.1 boron and molybdenum (MSU Well Water Special; GreenCare Fertilizers, Inc., Kankakee, IL).

Petunia and Rudbeckia were transplanted on 15 Oct. and 29 Oct., respectively, and Campanula and Coreopsis were transplanted on 29 Nov. into $12-\mathrm{cm}(591-\mathrm{mL})$ round plastic pots filled with a commercial peat and perlite medium (Suremix; Michigan Grower Products, Inc., Galesburg, MI) and then were transferred to NI treatments. At transplant, seedlings of Campanula, Coreopsis, Petunia, and Rudbeckia had a mean leaf number of eight, 10, eight, and six, respectively. All species were thinned to one seedling per plug cell on the day of transplant.

Night-interruption treatments. NI lighting was delivered from 2230 to $0230 \mathrm{HR}$ by either a 600-W rotating HPS lamp (Beamflicker; Parsource, Petaluma, CA) or 60-W INC lamps (Philips). The rotating HPS lamp was mounted $3.5 \mathrm{~m}$ above greenhouse benches at one gable end of the greenhouse, and 10 plants of each species were grown at each of five mean lateral distances from under the lamp: $1,4,7,10$, or $13 \mathrm{~m}$. At each distance, plants were positioned in straight lines perpendicular to the lamp. The maximum $P P F$ measured at plant level, as reported by Blanchard and Runkle (2009), decreased exponentially as the lateral distance from the rotating HPS lamp increased. At a lateral distance of $1,4,7,10$, or $13 \mathrm{~m}$ from the lamp, the maximum $P P F$ was $25.4,9.8,2.4,0.8$, or $0.3 \mu \mathrm{mol} \cdot \mathrm{m}^{-2} \cdot \mathrm{s}^{-1}$, respectively, whereas the maximum $P P F$ measured under INC lamps was $3.2 \mu \mathrm{mol} \cdot \mathrm{m}^{-2} \cdot \mathrm{s}^{-1}$. The integrated $P P F$ per night at a lateral distance of $1,7,10$, or $13 \mathrm{~m}$ from under the lamp was $0.1750,0.0160$, 0.0066 , or $0.0004 \mathrm{~mol} \cdot \mathrm{m}^{-2}$, respectively. Under the cyclic INC or continuous (CONT) INC, the integrated $P P F$ at night was 0.0092 or $0.0461 \mathrm{~mol} \cdot \mathrm{m}^{-2}$, respectively.

For INC NI lighting, four lamps at $1.0-\mathrm{m}$ spacing were mounted $0.8 \mathrm{~m}$ above the bench, and plants were illuminated either continuously for $4 \mathrm{~h}$ (CONT INC) or for 6 min every 30 min for $4 \mathrm{~h}$ (cyclic INC). Control plants were grown under an uninterrupted 15-h skotoperiod. Opaque black cloth was closed from 1700 to $0800 \mathrm{HR}$ everyday on benches with INC NI lighting and control plants. Plants under the rotating HPS received natural SD photoperiods (lat. $43^{\circ} \mathrm{N}$ ), and the calculated time from sunrise to sunset ranged from 9 to $12 \mathrm{~h}$ during the experiment.

Greenhouse environment. All plants were grown in a glass-glazed greenhouse at a constant temperature set point of $20^{\circ} \mathrm{C}$. Supplemental lighting was provided to all treatments from 0800 to $1700 \mathrm{HR}$ by HPS lamps that delivered a $P P F$ of 60 to 90 $\mu \mathrm{mol} \cdot \mathrm{m}^{-2} \cdot \mathrm{s}^{-1}$ at plant height. The HPS lamps were operated by an environmental computer and were turned on when the outside light intensity was less than $185 \mu \mathrm{mol} \cdot \mathrm{m}^{-2} \cdot \mathrm{s}^{-1}$ and turned off at greater than $370 \mu \mathrm{mol} \cdot \mathrm{m}^{-2} \cdot \mathrm{s}^{-1}$. Line quantum sensors (Apogee Instruments, Inc.) were positioned at plant height at 1,7 , 10 , and $13 \mathrm{~m}$ from the rotating HPS lamp, under CONT INC, and under the 15 -h skotoperiod. They measured the $P P F$ every $10 \mathrm{~s}$, and hourly averages were recorded by a CR10 data logger (CR10; Campbell Scientific, Logan, UT). The mean photosynthetic daily light integral measured at each location ranged from 6.7 to $7.6 \mathrm{~mol} \cdot \mathrm{m}^{-2} \cdot \mathrm{d}^{-1}$.

On each bench, air temperature was measured by an aspirated thermocouple [36-gauge (0.127-mm diameter) type E] every $10 \mathrm{~s}$, and hourly averages were recorded by a data logger. The actual MDT under all treatments ranged from 19.5 to $20.6{ }^{\circ} \mathrm{C}$. For treatments with black cloth (control plants and INC NI lighting), a data logger controlled a $1500-\mathrm{W}$ electric heater that provided supplemental heat during the night when the air temperature on each bench was less than $18.9^{\circ} \mathrm{C}$. Plants were irrigated as necessary with reverse osmosis water supplemented with a water-soluble fertilizer providing $\left(\mathrm{mg} \cdot \mathrm{L}^{-1}\right)$ 125 nitrogen, 12 phosphorus, 100 potassium, 65 calcium, 12 magnesium, 1.0 iron and copper, 0.5 manganese and zinc, 0.3 boron, and 0.1 molybdenum (MSU RO Water Special; GreenCare Fertilizers, Inc.).

Data collection and analysis. Plants were randomly assigned to treatments containing 10 plants each. On the day of transplant, the number of nodes was counted on each plant, and in all species except Petunia, the date of first macroscopic visible flower bud or inflorescence (subsequently referred to as VB) was recorded. VB was defined as the stage at which a flower bud or inflorescence became visible without dissection. Date of flowering was recorded for each plant when the first flower opened. Coreopsis and Rudbeckia were considered flowering when at least $50 \%$ of the ray flowers of an inflorescence were reflexed and Campanula and Petunia were considered flowering when one flower had opened. At flowering, the total number of $\mathrm{VB}$, plant height (from media surface to the base of the first open flower), and number of nodes below the first flower were recorded. Petunia that did not develop a VB within 12 weeks and Campanula, Coreopsis, and Rudbeckia that did not have a VB within 16 weeks from the start of treatments were considered nonflowering. Time to VB and total time to first flower and node count increase were calculated for each plant. Data were analyzed with the SAS (Version 9; SAS Institute, Cary, NC) mixed model procedure (PROC MIXED), and pairwise comparisons between treatments were performed with Tukey's honestly significant difference test at $P \leq 0.05$. Pearson correlation coefficients were determined for the relationship between time to flower and plant height using the SAS correlation procedure (PROC CORR).

Calculation of operating costs. The electricity and lamp costs to deliver a 4-h NI in a $139-\mathrm{m}^{2}$ greenhouse $(9.14 \times 15.24 \mathrm{~m})$ with either $40100-\mathrm{W}$ CONT or cyclic (6 min every $30 \mathrm{~min}$ ) INC lamps or one $600-\mathrm{W}$ rotating HPS lamp were compared. The INC lighting system consisted of five rows of lamps with eight lamps per row at $1.8-\mathrm{m}$ spacing and $1.8 \mathrm{~m}$ above the bench. This INC lighting design provides one $100-\mathrm{W}$ lamp per $3.5 \mathrm{~m}^{2}$, which is consistent with recommendations for the design of a photoperiod lighting system using INC lamps (Bickford and Dunn, 1972; Canham, 1966; Nelson, 2003). The rotating HPS lamp was connected to a 600-W electronic ballast (LK6120; Lumatek, Novato, CA). The amperage used to operate each lighting system with an input of $120 \mathrm{~V}$ was measured with a digital clampon meter (DL289; Universal Enterprises, Beaverton, OR) after lamps had been turned on for $15 \mathrm{~min}$. Purchase costs for a 100 W INC (100A/Soft White; SLI Lighting, Mullins, SC) and 600-W HPS (LU600; EiKO, Shawnee, KS) bulb were obtained from a commercial electrical supplier (Light Bulb Emporium, Englishtown, NJ) and were $\$ 0.48$ and $\$ 26.76$, respectively. Electrical cost was assumed to be $\$ 0.10 \mathrm{~kW} \cdot \mathrm{h}^{-1}$, which was the mean 2008 retail price for the commercial sector in the United States (Energy Information Administration, 2009). 


\section{Results}

Campanula carpatica 'Pearl Deep Blue'. All plants except those grown under a 9-h photoperiod developed a VB in 31 to $45 \mathrm{~d}$ (Fig. 1A). As the distance from the rotating HPS lamp increased from 1 to $13 \mathrm{~m}$, time to VB and flower increased linearly. Plants at $13 \mathrm{~m}$ from under the rotating HPS lamp developed a VB and flowered a mean of 11 to $14 \mathrm{~d}$ later than plants under CONT INC. There was no difference in time to $\mathrm{VB}$ or flower among plants grown under cyclic INC and at lateral distances of 1 to $10 \mathrm{~m}$ from the rotating HPS lamp. Plants at 1 and $4 \mathrm{~m}$ from the rotating HPS lamp had $58 \%$ more or greater flower buds than plants under CONT or cyclic INC or at 10 and $13 \mathrm{~m}$ from the rotating HPS (Table 1). As the distance from the rotating HPS lamp increased from 1 to $13 \mathrm{~m}$, plant height at flower decreased linearly from 47.3 to $33.9 \mathrm{~cm}$. Plants under CONT INC were a mean of $3.9 \mathrm{~cm}$ taller than plants at 10 or $13 \mathrm{~m}$ from the rotating HPS lamp. There was a correlation $(P \leq 0.001)$ between time to flower and plant height; as flowering time increased, plant height decreased. There were no significant differences in node number increase among treatments.

Coreopsis grandiflora 'Early Sunrise'. None of the plants flowered under a 9-h photoperiod, whereas $80 \%$ or more of plants had a VB and flowered under the NI treatments. Plants under CONT INC developed a VB and flowered 14 to $43 \mathrm{~d}$ earlier than plants grown at all lateral distances from under the rotating HPS lamp (Fig. 1B). There was no difference in time to VB and flower between CONT and cyclic INC. Plants grown at 1 or $4 \mathrm{~m}$ from the rotating HPS lamp had a mean of 14 to 17 more inflorescences at flower than plants under CONT or cyclic INC (Table 1). As the distance from the rotating HPS lamp increased from 1 to $13 \mathrm{~m}$, mean plant height at flower decreased linearly from 47.3 to 33.9 $\mathrm{cm}$ and inflorescence number decreased linearly from 29 to 18 . Node number increase ranged from 11 to 13 and was similar among treatments.

Petunia 'Easy Wave Coral Reef'. All plants that received NI flowered, whereas only $20 \%$ of plants flowered when grown under the 9-h photoperiod. As the lateral distance from under the rotating HPS lamp increased from 1 to $13 \mathrm{~m}$, time to flower increased linearly from 40 to $52 \mathrm{~d}$ (Fig. 1C). Plants under CONT INC or at 1 to $10 \mathrm{~m}$ from under the rotating HPS lamp flowered a mean of 10 to $16 \mathrm{~d}$ earlier than plants under cyclic INC or at $13 \mathrm{~m}$ from the rotating HPS lamp. Flower number was greatest under the CONT INC or at 1 to $7 \mathrm{~m}$ from under the rotating HPS lamp and decreased linearly as distance from the rotating HPS lamp increased (Table 1). Mean plant height at flower decreased linearly as the distance from under the rotating HPS increased from 1 to $13 \mathrm{~m}$. Plants under CONT INC were a mean of 6.1 to $9.6 \mathrm{~cm}$

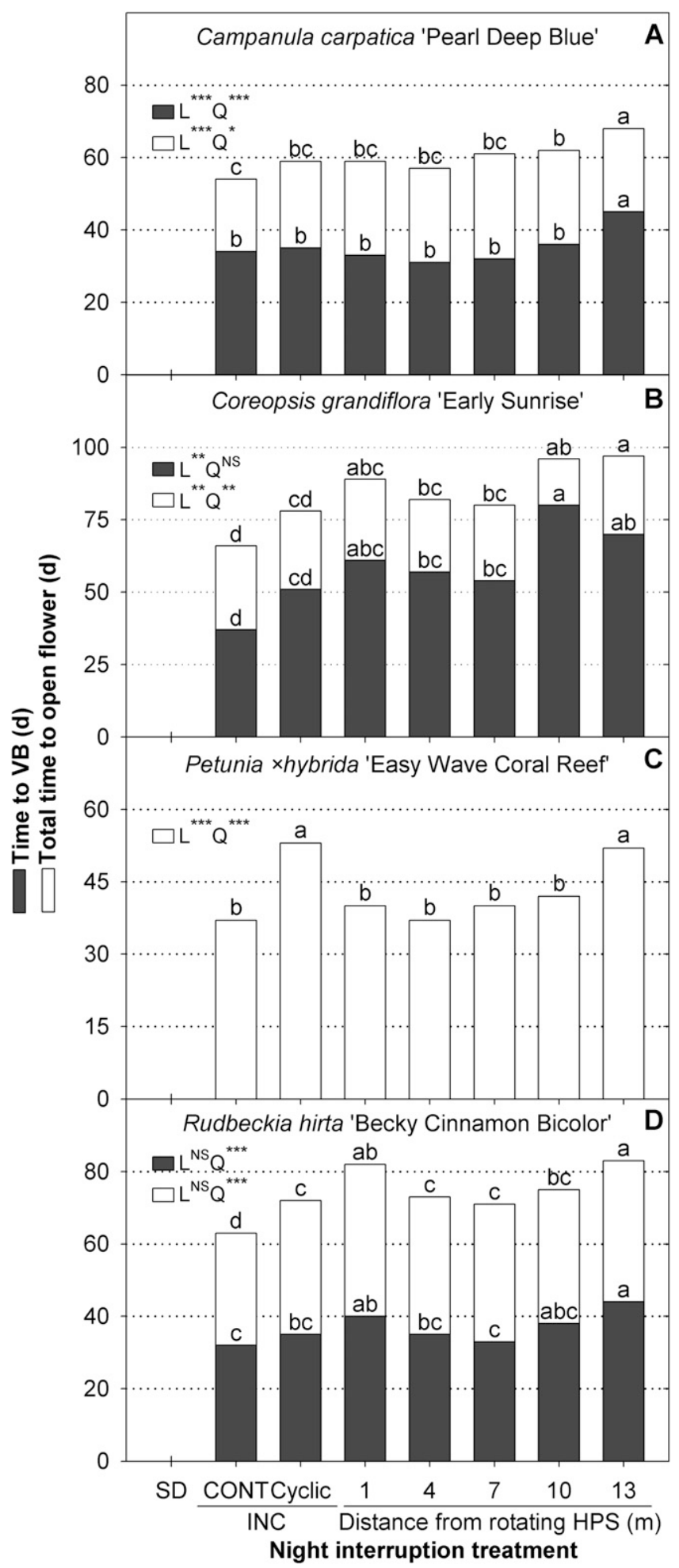

Fig. 1. The effects of 4-h night interruption (NI) lighting treatments on time to visible flower bud or inflorescence (VB) and total time to flower in four long-day species. Plants were grown at five lateral distances from under a stationary high-pressure sodium (HPS) lamp with an oscillating parabolic reflector (rotating HPS) or under incandescent (INC) lamps. INC lamps operated continuously for the entire NI (CONT INC) or for 6 min every $30 \mathrm{~min}$ for a 4-h period (cyclic INC). Control plants were grown under an uninterrupted 15-h skotoperiod [short day (SD)]. Time to VB was not recorded on Petunia. Bars for total time to flower represent the summation of time to VB and time from VB to flower. Mean separation within species and variable by Tukey's honestly significant difference test at $P \leq 0.05$. Linear $(\mathrm{L})$ and quadratic $(\mathrm{Q})$ trend analysis was performed only on data for rotating HPS. $\mathrm{ns}, *, * *, * * *$ Nonsignificant or significant at $P \leq 0.05,0.01$, or 0.001 , respectively.

taller at flower than all other plants except those grown at $1 \mathrm{~m}$ from the rotating HPS lamp. Plant height was negatively correlated
$(P \leq 0.001)$ with time to flower. Node number of flowering plants was similar among treatments. 
Table 1. The effects of 4-h night interruption (NI) lighting treatments on flowering in four long-day species. $^{2}$

\begin{tabular}{|c|c|c|c|}
\hline NI treatment & VB (no.) & $\begin{array}{c}\text { Ht at } \\
\text { flower }(\mathrm{cm})\end{array}$ & $\begin{array}{c}\text { Node } \\
\text { increase (no. }\end{array}$ \\
\hline \multicolumn{4}{|c|}{ Campanula carpatica Pearl Deep Blue } \\
\hline None (control) & 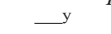 & - & - \\
\hline CONT INC & $26 \mathrm{bc}^{\mathrm{x}}$ & $12.0 \mathrm{a}$ & $14.8 \mathrm{a}$ \\
\hline Cyclic INC & $26 \mathrm{bc}$ & $11.2 \mathrm{ab}$ & $14.2 \mathrm{a}$ \\
\hline Rotating HPS $1 \mathrm{~m}$ & $41 \mathrm{a}$ & $13.3 \mathrm{a}$ & $15.7 \mathrm{a}$ \\
\hline Rotating HPS $4 \mathrm{~m}$ & $47 \mathrm{a}$ & $12.5 \mathrm{a}$ & $13.7 \mathrm{a}$ \\
\hline Rotating HPS $7 \mathrm{~m}$ & $38 \mathrm{ab}$ & $11.1 \mathrm{ab}$ & $13.7 \mathrm{a}$ \\
\hline Rotating HPS $10 \mathrm{~m}$ & $20 \mathrm{c}$ & $8.8 \mathrm{bc}$ & $14.9 \mathrm{a}$ \\
\hline Rotating HPS $13 \mathrm{~m}$ & $13 \mathrm{c}$ & $7.5 \mathrm{c}$ & $13.0 \mathrm{a}$ \\
\hline Rotating HPS $\mathrm{P}_{\text {Linear }}$ & $* * *$ & $* * *$ & NS \\
\hline Rotating HPS $\mathrm{P}_{\text {Quadratic }}$ & $* *$ & NS & NS \\
\hline \multicolumn{4}{|c|}{ Coreopsis grandiflora Early Sunrise } \\
\hline None (control) & - & - & - \\
\hline CONT INC & $14 \mathrm{bc}$ & $42.8 \mathrm{ab}$ & $10.6 \mathrm{a}$ \\
\hline Cyclic INC & $12 \mathrm{c}$ & $38.5 \mathrm{ab}$ & $11.8 \mathrm{a}$ \\
\hline Rotating HPS $1 \mathrm{~m}$ & $29 \mathrm{a}$ & $47.3 \mathrm{a}$ & $11.9 \mathrm{a}$ \\
\hline Rotating HPS $4 \mathrm{~m}$ & $28 \mathrm{a}$ & $42.3 \mathrm{ab}$ & $12.7 \mathrm{a}$ \\
\hline Rotating HPS $7 \mathrm{~m}$ & $25 \mathrm{ab}$ & $45.0 \mathrm{ab}$ & $11.2 \mathrm{a}$ \\
\hline Rotating HPS $10 \mathrm{~m}$ & $21 \mathrm{abc}$ & $36.6 \mathrm{~b}$ & $12.4 \mathrm{a}$ \\
\hline Rotating HPS $13 \mathrm{~m}$ & $18 \mathrm{abc}$ & $33.9 \mathrm{~b}$ & $12.1 \mathrm{a}$ \\
\hline Rotating HPS $\mathrm{P}_{\text {Linear }}$ & * & $* *$ & NS \\
\hline Rotating HPS $\mathrm{P}_{\text {Quadratic }}$ & NS & NS & NS \\
\hline \multicolumn{4}{|c|}{ Petunia $\times$ hybrida Easy Wave Coral Reef } \\
\hline None (control) & $\ldots w$ & - - & - - \\
\hline CONT INC & $43 \mathrm{abc}$ & $16.3 \mathrm{a}$ & $17.9 \mathrm{a}$ \\
\hline Cyclic INC & $21 \mathrm{~d}$ & $5.4 \mathrm{~d}$ & $20.4 \mathrm{a}$ \\
\hline Rotating HPS $1 \mathrm{~m}$ & $50 \mathrm{ab}$ & $12.5 \mathrm{ab}$ & $17.1 \mathrm{a}$ \\
\hline Rotating HPS $4 \mathrm{~m}$ & $60 \mathrm{a}$ & $10.2 \mathrm{bc}$ & $19.2 \mathrm{a}$ \\
\hline Rotating HPS $7 \mathrm{~m}$ & $44 \mathrm{abc}$ & $6.7 \mathrm{~cd}$ & $18.7 \mathrm{a}$ \\
\hline Rotating HPS $10 \mathrm{~m}$ & $38 \mathrm{bcd}$ & $6.8 \mathrm{~cd}$ & $20.0 \mathrm{a}$ \\
\hline Rotating HPS $13 \mathrm{~m}$ & $27 \mathrm{~cd}$ & $8.0 \mathrm{~cd}$ & $19.9 \mathrm{a}$ \\
\hline Rotating HPS $\mathrm{P}_{\text {Linear }}$ & $* * *$ & $* * *$ & NS \\
\hline Rotating HPS $\mathrm{P}_{\text {Quadratic }}$ & * & $* *$ & NS \\
\hline \multicolumn{4}{|c|}{ Rudbeckia hirta Becky Cinnamon Bicolor } \\
\hline None (control) & - & - & - \\
\hline CONT INC & $8 \mathrm{~b}$ & $19.5 \mathrm{a}$ & $8.0 \mathrm{a}$ \\
\hline Cyclic INC & $10 a b$ & $16.5 \mathrm{a}$ & $7.9 \mathrm{a}$ \\
\hline Rotating HPS $1 \mathrm{~m}$ & $13 a b$ & $19.8 \mathrm{a}$ & $6.4 \mathrm{a}$ \\
\hline Rotating HPS $4 \mathrm{~m}$ & $13 \mathrm{ab}$ & $17.7 \mathrm{a}$ & $7.3 \mathrm{a}$ \\
\hline Rotating HPS $7 \mathrm{~m}$ & $13 a b$ & $16.1 \mathrm{a}$ & $7.2 \mathrm{a}$ \\
\hline Rotating HPS $10 \mathrm{~m}$ & $13 a b$ & $17.6 \mathrm{a}$ & $6.5 \mathrm{a}$ \\
\hline Rotating HPS $13 \mathrm{~m}$ & $16 \mathrm{a}$ & $16.7 \mathrm{a}$ & $6.1 \mathrm{a}$ \\
\hline Rotating HPS $P_{\text {Linear }}$ & NS & NS & NS \\
\hline Rotating HPS $\mathrm{P}_{\text {Quadratic }}$ & NS & NS & NS \\
\hline
\end{tabular}

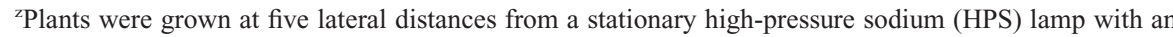
oscillating parabolic reflector (rotating HPS) or under incandescent (INC) lamps. INC lamps operated continuously for the entire NI (CONT INC) or for 6 min every $30 \mathrm{~min}$ for the 4-h period (cyclic INC). Control plants were grown under an uninterrupted 15 -h skotoperiod. Linear and quadratic trend analysis was performed only on data for rotating HPS. VB $=$ visible flower bud or inflorescence.

${ }^{y}$ No plants had a VB within 16 weeks.

${ }^{x}$ Mean separation within each species and column by Tukey's honestly significant difference test at $P \leq$ 0.05 .

${ }^{w} \leq 20 \%$ of plants had a VB within 12 weeks.

Ns, *,**,***Nonsignificant or significant at $P \leq 0.05,0.01$, or 0.001 , respectively.

Rudbeckia hirta 'Becky Cinnamon Bicolor'. All plants except those grown under a 9-h photoperiod developed a VB and flowered (Fig. 1D). Flowering occurred 8 to $20 \mathrm{~d}$ earlier in plants grown under CONT INC compared with that of all other treatments. Plants under CONT INC had half the number of inflorescences as plants grown at $13 \mathrm{~m}$ from the rotating HPS lamp (Table 1). All plants developed a mean of six to eight nodes, and there were no significant differences among flowering plants.

Operating costs. We estimate that a 4-h NI delivered from $40100-\mathrm{W}$ INC lamps operated continuously had an electrical con- sumption of $112 \mathrm{~kW} \cdot \mathrm{h}^{-1}$ per week, whereas $40100-\mathrm{W}$ cyclic INC lamps or one rotating HPS lamp consumed 22.4 and $18.8 \mathrm{~kW} \cdot \mathrm{h}^{-1}$ per week, respectively (Table 2). The total operating cost per week, including electricity and bulb costs, electrical consumption, and bulb lifespan, was calculated to be $\$ 11.56$, \$2.31, and \$1.92 for CONT INC, cyclic INC, and rotating HPS, respectively.

\section{Discussion}

All C. carpatica 'Pearl Deep Blue', $C$. grandiflora 'Early Sunrise', and $R$. hirta 'Becky Cinnamon Bicolor' grown under the 9-h photoperiod were vegetative after 16 weeks, indicating that these species are qualitative LD plants. When grown under SDs, all plants remained as a rosette, which is consistent with other photoperiod studies with these species (Blanchard and Runkle, 2009; Harkess and Lyons, 1994; Runkle et al., 1998; Whitman et al., 1998). Twenty percent of P. Xhybrida 'Easy Wave Coral Reef' flowered under the 9-h photoperiod and those plants flowered $34 \mathrm{~d}$ later than plants under CONT INC. In a similar study, all 'Easy Wave Coral Reef' grown under a 9-h photoperiod flowered within $57 \mathrm{~d}$, but flowering was delayed by $13 \mathrm{~d}$ and plants had 34 fewer flower buds than those grown under CONT INC (Blanchard and Runkle, 2009). These results suggest that $P$. $\times$ hybrida 'Easy Wave Coral Reef' is a quantitative LD plant but horticulturally could be considered a qualitative LD plant.

At all lateral distances from under the rotating HPS lamp, at least $80 \%$ of the plants within each species perceived the NI as an $\mathrm{LD}$ as indicated by the promotion of flowering. These results are consistent with those of Blanchard and Runkle (2009), who reported that the same LD species grown under NI from a rotating HPS lamp had characteristic LD growth habits (e.g., upright leaves and elongated stems) within $28 \mathrm{~d}$. Therefore, the maximum light intensity measured at a lateral distance of $13 \mathrm{~m}$ from the rotating HPS lamp $\left(\approx 0.3 \mu \mathrm{mol} \cdot \mathrm{m}^{-2} \cdot \mathrm{s}^{-1}\right)$ is apparently above the threshold irradiance value to elicit a photoperiodic flowering response in these LD species, even when delivered cyclically (Summerfield and Roberts, 1987). However, flowering was delayed by 14 to $31 \mathrm{~d}$ in plants grown at $13 \mathrm{~m}$ from the rotating HPS lamp compared with that of plants grown under CONT INC. Whitman et al. (1998) calculated that the threshold irradiance for flowering in C. grandiflora 'Early Sunrise' and C. carpatica 'Blue Clips' grown under a 7-h day extension from a stationary HPS lamp was 0.05 to $0.1 \mu \mathrm{mol} \cdot \mathrm{m}^{-2} \cdot \mathrm{s}^{-1}$. Flowering was accelerated as irradiance increased to a saturation of 0.2 to $0.7 \mu \mathrm{mol} \cdot \mathrm{m}^{-2} \cdot \mathrm{s}^{-1}$.

Plants of C. grandiflora 'Early Sunrise' and $R$. hirta 'Becky Cinnamon Bicolor' flowered 8 to $31 \mathrm{~d}$ earlier when grown under a 4-h NI delivered continuously from INC lamps compared with that of plants grown at all lateral distances from the rotating HPS lamp. The different flowering responses between light sources could be attributed to the illumination frequency, spectral distribution of the lamp, or both. Flowering in LD plants is generally enhanced when the photoperiod has a moderate to low red (R, 600 to $700 \mathrm{~nm}$ ) to far-red (FR, 700 to $800 \mathrm{~nm}$ ) ratio (Runkle and Heins, 2001; Vince-Prue, 1975). Thus, lamps that emit a low R:FR (e.g., INC) can be more effective in promoting flowering in some LD species than lamps with a higher ratio (e.g., cool-white fluorescent) (Cathey and Campbell, 1975; Downs and Thomas, 1982; Lane et al., 1965). Padhye and Runkle (2009) reported that a 4-h NI delivered continuously from compact fluorescent 
Table 2. Comparison of operating costs (US\$) to deliver 4-h night interruption (NI) lighting regimens in a $139-\mathrm{m}^{2}$ greenhouse from $100-\mathrm{W}$ incandescent (INC) lamps operated continuously for the entire NI (CONT INC) or for 6 min every $30 \mathrm{~min}$ for a 4-h period (cyclic INC) or from a stationary 600-W highpressure sodium (HPS) lamp with an oscillating parabolic reflector (rotating HPS). ${ }^{\mathrm{z}}$

\begin{tabular}{lccc}
\hline & \multicolumn{2}{c}{ NI treatment } \\
\cline { 2 - 4 } & CONT INC & Cyclic INC & Rotating HPS \\
\hline Fixtures per greenhouse & 40 & 40 & 1 \\
Electrical costs & & & \\
Electrical energy consumed per fixture $(\mathrm{W})$ & 100 & 100 & $673^{y}$ \\
Electricity used per greenhouse $(\mathrm{kW})$ & 4.0 & 4.0 & 0.673 \\
Time operated per week $(\mathrm{h})$ & 28.0 & 5.6 & 28.0 \\
Electricity used per week $\left(\mathrm{kW} \cdot \mathrm{h}^{-1}\right)$ & 112.0 & 22.4 & $\$ 1.88$ \\
Electrical cost per week $\left(\$ 0.10\right.$ per $\left.\mathrm{kW} \cdot \mathrm{h}^{-1}\right)$ & $\$ 11.20$ & $\$ 2.24$ & $\$ 26.76$ \\
Lamp costs & & & 24,000 \\
Bulb cost (each) & $\$ 0.48$ & $1,500.48$ & 857.1 \\
Bulb lifespan $(\mathrm{h})$ & 1,500 & 268.0 & $\$ 0.03$ \\
Bulb life (weeks) & 53.6 & $\$ 0.06$ & $\$ 1.92$ \\
Bulb cost per greenhouse per week & $\$ 0.31$ & $\$ 2.31$ & \\
Total operating cost per greenhouse per week & $\$ 11.56$ & & \\
\hline
\end{tabular}

"See "Materials and Methods" for more information on calculations.

yncludes a $670-\mathrm{W}$ lamp and ballast and a $3-\mathrm{W}$ oscillating reflector.

lamps (R:FR = 8.4) delayed flowering of Petunia 'Wave Purple' by $21 \mathrm{~d}$ compared with the same NI but with INC lamps. In our study, the R:FR under INC lamps was calculated to be 0.6 , whereas the R:FR under the rotating HPS lamp at 1 to $7 \mathrm{~m}$ was considerably higher, 4.9 .

Flowering of Petunia 'Easy Wave Coral Reef' and R. hirta 'Becky Cinnamon Bicolor' was delayed by 9 to $16 \mathrm{~d}$ when plants were grown under INC lamps that operated cyclically compared with that of plants under the continuous 4-h NI. These results are in agreement with those of Blanchard and Runkle (2009), who reported a 7- to 8-d delay in flowering in the same species grown under cyclic INC versus continuous INC. There was no difference in flowering time of $C$. carpatica 'Pearl Deep Blue' and C. grandiflora 'Early Sunrise' between the two INC lighting strategies. Collectively, these results support the conclusion by Runkle et al. (1998) that flowering in some LD species grown under NI delivered with cyclic INC lamps may be incomplete, delayed, or nonuniform compared with that of plants grown under INC lamps that are on for the entire NI.

Petunia that received NI from CONT INC were $60 \%$ to $143 \%$ taller than plants grown at 4 to $13 \mathrm{~m}$ from under the rotating HPS. Blanchard and Runkle (2009) reported that Petunia grown under NI from CONT INC were $68 \%$ to $169 \%$ taller at flower than plants grown under rotating HPS. The increased stem elongation under CONT INC could be caused by the increased exposure of the lower $\mathrm{R}: F R$ ratio compared with that of the cyclic lighting treatments. FR light promotes stem elongation and plant height is suppressed under an environment with a high R:FR ratio (Runkle and Heins, 2001). Previous studies with photoperiodic lighting have also reported greater stem elongation under INC lamps compared with HPS lamps (Cathey and Campbell, 1975; Whitman et al., 1998). Interestingly, petunia was substantially shorter at flowering under cyclic INC compared with CONT INC, which suggests that

\section{Literature Cited}

Armitage, A.M. 1983. Determining optimum sowing time of bedding plants for extended marketing periods. Acta Hort. 147:143-152.

Bickford, E.D. and S. Dunn. 1972. Lighting for plant growth. Kent State Univ. Press, Kent, OH.

Blanchard, M.G. and E.S. Runkle. 2009. Effects of a new cyclical lighting system on flower induction in long-day plants: A preliminary investigation. Acta Hort. 813:623-630.

Cameron, A.C., S.R. Padhye, and C.M. Whitman. 2007. Control of flowering in herbaceous perennials. Acta Hort. 755:112-119.

Canham, A.E. 1966. The fluorescent tube as a source of night-break light. Expt. Hort. 16:53-68.

Cathey, H.M. and L.E. Campbell. 1975. Effectiveness of five vision-lighting sources on photoregulation of 22 species of ornamental plants. J. Amer. Soc. Hort. Sci. 100:65-71.

Dole, J.M. and H.M. Wilkins. 2004. Floriculture: Principles and species. 2nd Ed. Prentice Hall, Upper Saddle River, NJ.

Downs, R.J. and J.F. Thomas. 1982. Phytochrome regulation of flowering in the long-day plant, Hyoscyamus niger. Plant Physiol. 70:898-900.

the R:FR and duration of exposure to the ratio influence stem extension.

A cyclic lighting system can be used to reduce electrical consumption or to provide greater coverage of the growing area when the capacity of the electrical system is limited (Bickford and Dunn, 1972; Nell and Joiner, 1980). We estimate that a 4-h NI delivered from 40 100-W INC lamps operated cyclically $(20 \%$ on) or one $600-\mathrm{W}$ rotating HPS lamp consumed five to six times less electricity than INC lamps operated continuously. HPS ballasts are considerably more efficient at converting electrical energy to light compared with INC lamps (Bickford and Dunn, 1972). For example, according to the manufacturer's specifications for new lamps, a 600-W HPS lamp with an electronic ballast emits a $P P F$ of $1.6 \mu \mathrm{mol} \cdot \mathrm{m}^{-2} \cdot \mathrm{s}^{-1}$ per watt of electricity, whereas a $100-\mathrm{W}$ INC lamp produces only $0.3 \mu \mathrm{mol} \cdot \mathrm{m}^{-2} \cdot \mathrm{s}^{-1}$ per electrical watt. Therefore, because of the greater energy efficiency of HPS lamps and the increased growing area that can be lighted with an oscillating parabolic reflector, operating costs per week are estimated to be $83 \%$ lower with one rotating HPS compared with 40 CONT INC lamps. However, purchase, maintenance, and installation of each lighting system should also be considered.

We conclude that a rotating HPS lamp operated continuously during a 4-h NI was effective at promoting flower induction in these LD species and consumed less energy compared with INC lamps operated continuously. However, when the maximum NI light intensity received from a rotating HPS lamp was less than $2.4 \mu \mathrm{mol} \cdot \mathrm{m}^{-2} \cdot \mathrm{s}^{-1}$, flowering was either delayed or VB number at flowering was reduced in some species compared with plants under higher NI light intensities. We believe that flowering uniformity in a population of plants grown under rotating HPS would be acceptable for commercial production as long as the light intensity is above this value. Additional rotating HPS lamps would be necessary if the coverage of the growing area was not adequate.
Energy Information Administration. 2009. Electric power monthly April 2009. U.S. Dept. of Energy, Washington, DC.

Erwin, J. and E. Runkle. 2007. New directions for scheduling bedding plants. Greenhouse Product News 17(3):50-54.

Erwin, J.E. and R.M. Warner. 2002. Determination of photoperiodic response group and effect of supplemental irradiance on flowering of several bedding plant species. Acta Hort. 580:95-101.

Harkess, R.L. and R.E. Lyons. 1994. Floral initiation in Rudbeckia hirta (Asteraceae) under limited inductive photoperiodic treatments. Amer. J. Bot. 81:1021-1026.

Johansson, J. 1976. The regulation of growth and flowering in Calceolaria $\times$ speciosa Lilia. Acta Hort. 64:239-244.

Lane, H.C., H.M. Cathey, and L.T. Evans. 1965. The dependence of flowering in several longday plants on the spectral composition of light extending the photoperiod. Amer. J. Bot. 52: 1006-1014.

Maginnes, E.A. and R.W. Langhans. 1967. Flashing light affects the flowering of snapdragons. New York State Flower Growers Bul. 261:1-3.

Mattson, N.S. and J.E. Erwin. 2005. The impact of photoperiod and irradiance on flowering of several herbaceous ornamentals. Scientia Hort. 104:275-292.

Nell, T.A. and J.N. Joiner. 1980. Saving energy with cyclic lighting. Florists' Rev. 166:56

Nelson, P.V. 2003. Greenhouse operation and management. 6th Ed. Prentice Hall, Upper Saddle River, NJ.

Omi, S.K. and K.L. Eggleston. 1993. Photoperiod extension with two types of light sources: Effects on growth and development of conifer species. Tree Planter's Notes 44:105-112.

Padhye, S. and E. Runkle. 2009. Providing longdays with CFLs. GrowerTalks 72(11):58-62.

Runkle, E., R. Heins, A. Cameron, and W. Carlson. 2001. Minireview of research activity: Horticultural flowering of herbaceous perennials. Flowering Nwsl. 31:34-43.

Runkle, E.S. and R.D. Heins. 2001. Specific functions of red, far red, and blue light in flowering and stem extension of long-day plants. J. Amer. Soc. Hort. Sci. 126:275-282.

Runkle, E.S., R.D. Heins, A.C. Cameron, and W.H. Carlson. 1998. Flowering of herbaceous perennials under various night interruption and 
cyclic lighting treatments. HortScience 33: 672-677.

Summerfield, R.J. and E.H. Roberts. 1987. Effects of illuminance on flowering in long- and short-day grain legumes: A reappraisal and unifying model, p. 203-223. In: Atherton, J.G. (ed.). Manipulation of flowering. Butterworths, Kent, UK.

Tinus, R.W. 1995. New greenhouse photoperiod lighting system for prevention of seed- ling dormancy. Tree Planter's Notes 46: $11-14$.

U.S. Dept. of Agriculture Forest Service. 2001. Scientist invents greenhouse lighting device. Southern Research Station News Release, 18 June 2001, Ashville, NC.

U.S. Patent Office. 1992. Greenhouse illumination system. Patent No. 5,095,414. Patented 10 Mar. 1992.
Vince-Prue, D. 1975. Photoperiodism in plants. McGraw-Hill, London, UK.

Whitman, C.M., R.D. Heins, A.C. Cameron, and W.H. Carlson. 1998. Lamp type and irradiance level for daylength extensions influence flowering of Campanula carpatica 'Blue Clips', Coreopsis grandiflora 'Early Sunrise', and Coreopsis verticillata 'Moonbeam'. J. Amer. Soc. Hort. Sci. 123:802-807. 